\title{
Histamine levels in plasma, blood, and urine in severe asthma, and the effect of corticosteroid treatment
}

\author{
CHRISTINE BRUCE, R. WEATHERSTONE, \\ A. SEATON, and W. H. TAYLOR \\ Department of Chemical Pathology, Liverpool Area Health Authority (Teaching) \\ and Asthma Research Unit, Sully Hospital, Cardiff
}

\begin{abstract}
Bruce, Christine, Weatherstone, R., Seaton, A., and Taylor, W. H. (1976). Thorax, 31, 724-729. Histamine levels in plasma, blood, and urine in severe asthma, and the effect of corticosteroid treatment. Plasma, whole blood, and urinary histamine levels have been determined in 64 normal subjects, in 10 patients with severe asthma, and in 10 control patients with other illnesses. The mean whole blood levels did not differ between the three groups. The mean plasma level in the asthmatics was significantly greater than that of the normal subjects but not of the control patients. The urinary histamine output was lower in the control patients than in the normal subjects but in the asthmatics did not differ from that of the normals. Corticosteroid therapy caused a marked fall, often to barely detectable levels, of the whole blood histamine concentration of the asthmatic patients and restored the plasma levels to normal but did not affect urinary histamine levels.
\end{abstract}

The role played by histamine in the production of asthmatic symptoms remains controversial. While histamine infusions or inhalations may provoke symptoms more easily in asthmatics than in normal subjects (Herxheimer, 1951) and histamine is liberated on challenge of asthmatic lung in vivo (Schild et al., 1951), histamine levels in blood have only rarely been found to be much raised in asthmatics (Rose, Rusted, and Fownes, 1950; Dunér and Pernow, 1960; Porter and Mitchell, 1970). In general, blood histamine relates closely to the blood basophil count (Code and Mitchell, 1957). Urine histamine excretion relates in normal subjects to blood histamine levels but seems to become reduced paradoxically in an acute asthmatic attack (Dunér and Pernow, $1958 \mathrm{a}$ and $\mathrm{b}$ ). Corticosteroids in normal man and in animals reduce the blood and lung histamine levels, and this relates to their effect on the blood basophil count also (Code and Mitchell, 1957; Noah and Brand, 1957; Aviado and Carrillo, 1970). The proportions of histamine to its principal metabolites, 1-methyl histamine and 1methyl-imidazole-4-acetic acid, do not seem to vary greatly between normals and asthmatics (Mitchell, Thom, and Richardson, 1974).
Since most of the blood histamine is found in $\overline{\vec{a}}$ cells, whereas much of the substance liberated during an asthmatic attack is presumably extracellular, it is desirable to measure plasma levels of histamine in asthmatic subjects and to relate $\vec{\partial}$ these to blood and urine levels. Previous attempts, using sensitive bioassay techniques (Porter and:Mitchell, 1970), have failed to demonstrate hista-3. mine in the plasma of asthmatics. We have chosen to study patients with severe exacerbations 3 of asthma before and during treatment with cor-o ticosteroids, comparing the results with those from normal subjects and from a control groupo of subjects with other non-allergic respiratory disorders requiring hospitalization. We have used $\tilde{N}$ a newly developed and sensitive enzymatic isotopic N technique for the estimation of histamine.

\section{SUBJECTS AND METHODS}

SUBJECTS The normal subjects were mainly members of the laboratory staff at Liverpool. Thirtyfour were male and 30 were female. Their ageso ranged from 20 to 65 years.

The study protocol was approved by the area $\frac{?}{\oplus}$ ethical committee, and 20 patients gave informed $\frac{0}{0}$ 
consent to taking part. Ten were severe asthmatics admitted to hospital for urgent treatment. All were selected on the basis of the following criteria:

(a) pulse rate of 110 per minute or greater;

(b) $\mathrm{PaO}_{2}$ of $9.3 \mathrm{kPa}(70 \mathrm{mmHg})$ or less;

(c) peak expiratory flow rate of less than $25 \%$ that predicted for a normal subject of the same height and weight;

(d) previous or subsequent demonstration of widely variable airways obstruction.

Their mean age was 49 (range 21-81) years. Six had positive immediate cutaneous reactions to two or more common allergens. Eight were female.

The 10 control patients were admitted to hospital over the same period for investigation and treatment of tuberculosis (4 patients), bronchial carcinoma (2), emphysema (1), bronchial stenosis (1), bronchiectasis (1), and pancreatic carcinoma (1). Their mean age was 52 (range 26-69) years; eight were female and all were inpatients for at least 14 days. None was receiving corticosteroids and none had a history or ventilatory response to bronchodilators suggestive of asthma.

EXPERIMENTAL PROCEDURE Twenty millilitres of venous blood was taken on admission into lithium heparin bottles precooled to $4^{\circ} \mathrm{C}$. Ten millilitres was frozen immediately and $10 \mathrm{ml}$ was spun down at $1800 \mathrm{~g}$ for 10 minutes, the plasma being removed and frozen. Care was taken not to disturb the buffy coat on removal of the plasma. A 24hour urine sample was collected and measured, and a $10 \mathrm{ml}$ aliquot was frozen. Blood, plasma, and urine samples were stored at $-20^{\circ}$. Immediately after the venepuncture, treatment of the asthmatics was begun with intravenous hydrocortisone, $1 \mathrm{~g}$ every six hours, aminophylline, and nebulized salbutamol. The hydrocortisone dose was reduced over three to four days and prednisone was substituted, and by the 14th day this had usually been reduced to between 15 and 2.5 $\mathrm{mg}$ daily, according to the patient's response. Venous blood and urine samples were obtained similarly on day 3 and day 14 in both patients and controls.

DETERMINATION OF HISTAMINE Histamine was determined by a modification of the method of Miller et al. (1970) which was, in turn, based upon that of Snyder, Baldessarini, and Axelrod (1966), in which histamine is converted to 1methyl histamine, in the presence of the enzyme, imidazole-N-methyl transferase, with S-adenosylmethionine as the methyl donor. Further modif- cations made by Beaven, Jacobsen, and Horáková (1971) eliminate the need for the extraction step of Miller et al. and the use of labelled histamine as an internal standard by Snyder et al. We have increased the sensitivity of the method by using S-adenosylmethionine $\left({ }^{3} \mathrm{H}_{3}\right.$-methyl) of high specific activity $(500 \mathrm{mCi} / \mathrm{mmol}$, Radiochemical Centre, Amersham), by adding human $\gamma$-globulin (Sigma Co, London) to our aqueous standards in order to achieve an approximate quantitative identity with plasma samples, and by using fresh pig brain instead of guinea-pig brain as the enzyme source. Approximately $800 \mathrm{~g}$ of brain from six pigs was homogenized in two volumes of aqueous $0.25 \mathrm{M}$ sucrose at $4^{\circ} \mathrm{C}$. The extraction of the enzyme was then carried out according to the method of Lorenz et al. (1972). Glassware was soaked in Decon 90 (May and Baker, Dagenham, England) before use and washed four times with glass-distilled water.

For plasma, using glass-stoppered test-tubes, a mixture of $300 \mu \mathrm{l} 0.1 \mathrm{M}$ phosphate buffer at $\mathrm{pH}$ $7 \cdot 4\left(0.1 \mathrm{M} \mathrm{Na}_{2} \mathrm{HPO}_{4}\right.$ and $\left.0.1 \mathrm{M} \mathrm{KH}_{2} \mathrm{PO}_{4}\right)$ and 100 $\mu l$ of the plasma was boiled for two minutes to destroy any endogenous S-adenosylmethionine. Standards containing $1 \cdot 12,2 \cdot 25,4 \cdot 5$, and $9.0 \mathrm{pmol}$ histamine in $300 \mu \mathrm{l}$ of buffer and $100 \mu \mathrm{l}$ of $\gamma$-globulin solution $\left(50 \mathrm{mg} \mathrm{ml}^{-1}\right.$ in phosphate buffer) were set up and treated similarly. After cooling, $50 \mu \mathrm{l}$ of the enzyme solution $\left(1 \mathrm{mg}\right.$ protein $\mathrm{ml}^{-1}$ in the phosphate buffer) and $1 \mu l$ of S-adenosylmethionine $(1.2 \mathrm{nmol})$ were added to each tube, which was then incubated at $37^{\circ} \mathrm{C}$ for 30 minutes. The reaction was stopped by the addition of $200 \mu 1$ $0.4 \mathrm{M}$ perchloric acid containing 1-methylhistamine $\left(5 \cdot 1 \mu \mathrm{mol} \mathrm{ml}^{-1}\right)$. The unlabelled 1-methylhistamine displaces any labelled compound that is adhering to glass. Two hundred microlitres $10 \mathrm{M}$ aqueous $\mathrm{NaOH}$ and $5 \mathrm{ml}$ of chloroform were added to each tube and mixed for 1 minute on a Rotamixer (Hook and Tucker, Ltd, London). The tubes were then centrifuged at $2000 \mathrm{~g}$ for 10 minutes and the aqueous layer was discarded. The chloroform layer was washed with $1 \mathrm{ml} 3.3 \mathrm{M}$ aqueous $\mathrm{NaOH}$ and the aqueous layer was again discarded after mixing and centrifugation. Three millilitres of the chloroform extract were then transferred to a scintillation vial and evaporated to dryness; $10 \mathrm{ml}$ of scintillation fluid (100 g naphthalene; 1, 4 Di-2(5 phenyl oxazolyl) benzene (POPOP) $300 \mathrm{mg}$; 2, 5, Diphenyloxaxole (PPO) $7 \mathrm{~g}$; dissolved in 11 . of 1,4 Dioxan) were then added and the activity was counted.

For whole blood, the standards were 18, 45, 90, and $180 \mathrm{pmol}$. Because of the higher histamine 
levels in blood as compared with plasma it was not necessary to add either $\gamma$-globulin or 1-methyl histamine in the assay. For urine, the sample volume was $20 \mu 1$, and the standards corresponded to those for the plasma assay. Again, no $\gamma$-globulin nor 1-methyl histamine was needed.

SENSITIVITY AND PRECISION OF THE HISTAMINE ASSAY The lowest limit of detection in plasma was $0.18 \mathrm{pmol}(0.02 \mathrm{ng})$, which gave a plasma level of $1.8 \mathrm{nmol}^{-1}$. The sensitivity of the urine histamine assay was of the same order. For whole blood histamine, the lowest limit of detection was $1.8 \mathrm{pmol}$ of histamine $(0.2 \mathrm{ng})$, which gave a whole blood histamine level of $18 \mathrm{nmol} \mathrm{l}^{-1}$.

Recovery experiments were carried out by adding varying amounts of histamine standard to each biological fluid at the beginning of the assay procedure. The amounts added were of the same order as the histamine present in the sample. The mean percentage recoveries were as follows: plasma $89.4 \%$, whole blood $116 \%$, and urine $84.5 \%$. The coefficients of variation were plasma $25.9 \%$ whole blood $9.9 \%$, and urine $9.1 \%$. In order to obtain a further measure of the precision of the plasma assay, eight samples were estimated on two different occasions (of widely differing values). The precision was calculated using the formula of Snedecor (1952) and gave a value of $\pm 2.6 \mathrm{nmol} 1^{-1}$.

SUBSTRATE SPECIFICITY Histidine and 5-hydroxy- $\stackrel{\mathbb{Q}}{\varrho}$ tryptamine may both be present in human blood. के It was found experimentally, however, that $\vec{\circ}$ neither had any effect upon the assay when added in final concentrations of $40.0 \mu \mathrm{M}$ for histidine $\vec{\omega}$ and up to $1.27 \mu \mathrm{M}$ for 5-hydroxytryptamine.

\section{RESULTS}

The normal values in healthy adults for our techniques are given in Table $I$. The results in our patients are given in Table II.

The only significant differences between controls and asthmatics were for blood histamine on 0 day 3, which was lower in the asthmatics $(\mathrm{P}<0.001)$ and for plasma histamine on day 14 , which was also lower in the asthmatic group $(\mathrm{P}<0.05)$. In the control group, there were no statistically significant differences in plasma, blood or urinary histamine between the three days on which samples were collected. The blood histamine in asthmatics on day 3 was significantly lower than that on day $1(\mathrm{P}<0.01)$ and on day 14 $(\mathrm{P}<0.001)$. The urinary histamine concentration did not differ significantly between asthmatics and control patients, though there was a tendency for

T A B L E I

PLASMA, WHOLE BLOOD, AND URINARY HISTAMINE LEVELS OF NORMAL HEALTHY ADULTS

\begin{tabular}{|c|c|c|c|c|}
\hline & \multirow{2}{*}{$\begin{array}{l}\text { No. of } \\
\text { Subjects }\end{array}$} & \multirow{2}{*}{ Age Range } & \multicolumn{2}{|c|}{ Histamine Concentration } \\
\hline & & & Mean \pm SD & Range \\
\hline $\begin{array}{l}\text { Plasma } \\
\text { Blood } \\
\text { Urine }\end{array}$ & $\begin{array}{l}29 \\
32 \\
16\end{array}$ & $\begin{array}{l}20-65 \\
20-60 \\
20-35\end{array}$ & 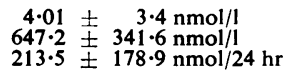 & $\begin{array}{r}0-10 \cdot 8 \\
306-989 \\
34 \cdot 6-482\end{array}$ \\
\hline
\end{tabular}

T A B L E I I

PLASMA, WHOLE BLOOD, AND URINARY HISTAMINE LEVELS OF 10 PATIENTS WITH SEVERE ASTHMA ADMITTED URGENTLY, AND OF 10 CONTROL PATIENTS 1

\begin{tabular}{|c|c|c|c|c|c|c|c|c|c|c|}
\hline \multirow{2}{*}{ Day } & & \multicolumn{3}{|c|}{$\underset{\left(\text { nmol 1 }^{-1}\right)}{\text { Plasma }}$} & \multicolumn{3}{|c|}{$\begin{array}{l}\text { Whole Blood } \\
\text { (nmol 1-1) }\end{array}$} & \multicolumn{3}{|c|}{$\begin{array}{c}\text { Urine } \\
(\mathrm{nmol} / 24 \mathrm{hr})\end{array}$} \\
\hline & & $\begin{array}{l}\text { Control } \\
\text { Patients }\end{array}$ & $\begin{array}{l}\text { Asthmatic } \\
\text { Patients }\end{array}$ & $\mathbf{P}$ & $\begin{array}{l}\text { Control } \\
\text { Patients }\end{array}$ & $\begin{array}{c}\text { Asthmatic } \\
\text { Patients }\end{array}$ & $\mathbf{P}$ & $\begin{array}{l}\text { Control } \\
\text { Patients }\end{array}$ & $\underset{\text { Patients }}{\text { Asthmatic }}$ & $\mathbf{P}$ \\
\hline $\begin{array}{r}1 \\
3 \\
14\end{array}$ & $\begin{array}{l}\text { Mean } \\
\text { SD } \\
\text { Mean } \\
\text { SD } \\
\text { Mean } \\
\text { SD }\end{array}$ & $\begin{array}{r}6 \cdot 1 \\
3 \cdot 8 \\
7 \cdot 0 \\
6 \cdot 6 \\
10 \cdot 4 \\
6 \cdot 4\end{array}$ & $\begin{array}{l}9 \cdot 0 \\
8 \cdot 9 \\
4 \cdot 3 \\
3 \cdot 7 \\
5 \cdot 1 \\
4 \cdot 4\end{array}$ & $\begin{array}{c}0.4>P>0.3 \\
n=20 \\
0.3>P>0.2 \\
n=19 \\
0.05>P>0.02 * \\
n=19\end{array}$ & $\begin{array}{l}607 \cdot 7 \\
338 \cdot 0 \\
543 \cdot 9 \\
261 \cdot 6 \\
648 \cdot 2 \\
489 \cdot 1\end{array}$ & $\begin{array}{r}641 \cdot 0 \\
721 \cdot 9 \\
21 \cdot 6 \\
8 \cdot 5 \\
338 \cdot 9 \\
250 \cdot 8\end{array}$ & $\begin{array}{c}0.9>P>0.8 \\
n=18 \\
P<0.001^{*} \\
n=20 \\
0.1>P>0.05 \\
n=18\end{array}$ & $\begin{array}{l}36 \cdot 9 \\
39 \cdot 6 \\
50 \cdot 3 \\
36 \cdot 0 \\
62 \cdot 9 \\
69 \cdot 2\end{array}$ & $\begin{array}{r}81 \cdot 8 \\
101 \cdot 6 \\
96 \cdot 2 \\
73 \cdot 7 \\
100 \cdot 7 \\
57 \cdot 5\end{array}$ & $\begin{array}{c}0.3>P>0.2 \\
n=18 \\
0.1>P>0.05 \\
n=20 \\
0.3>P>0.2 \\
n=18\end{array}$ \\
\hline
\end{tabular}

${ }^{1}$ The effect of treatment at days 3 and 14 is also shown, together with the statistical probability that the two groups are from different populations. The statistically significant differences are marked with an asterisk. 
T A B L E I I I

PROBABILITY VALUES FOR COMPARISON OF HISTAMINE VALUES IN NORMAL SUBJECTS WITH THOSE IN $(A)$ CONTROL PATIENTS AND $(B)$ ASTHMATIC PATIENTS

\begin{tabular}{|c|c|c|c|c|c|c|}
\hline \multirow[b]{2}{*}{ Day } & \multicolumn{2}{|c|}{ Plașma } & \multicolumn{2}{|c|}{ Whole Blood } & \multicolumn{2}{|c|}{ Urine } \\
\hline & Controls & Asthmatics & Controls & Asthmatics & Controls & Asthmatics \\
\hline $\begin{array}{r}1 \\
3 \\
14\end{array}$ & $\begin{array}{c}0.1>P>0.05 \\
0.1>\mathbf{P}>0.05 \\
0.01>P>0.001\end{array}$ & $\begin{array}{c}0.02>P>0.01^{*} \\
0.5>P>0.4 \\
0.3>P>0.2\end{array}$ & $\begin{array}{c}0.8>P>0.7 \\
0.4>P>0.3 \\
P>0.9\end{array}$ & $\begin{array}{c}\mathbf{P}>0.9 \\
\mathbf{P}<0.001 * \\
0.02>\mathbf{P}>0.01^{*}\end{array}$ & $\begin{array}{l}0.01>\mathrm{P}>0.001^{*} \\
0.01>\mathrm{P}>0.001^{*} \\
0.02>\mathrm{P}>0.01^{*}\end{array}$ & $\begin{array}{l}0.1>P>0.05 \\
0.1>P>0.05 \\
0.1>P>0.05\end{array}$ \\
\hline
\end{tabular}

Statistically significant differences are indicated by an asterisk, using Student's $t$ test for comparison of means.

the values to be higher in asthmatics, especially on day $3(0.05<P<0.1)$, and both groups showed results usually at the lower end of our range for healthy adults. Three asthmatics, however, each showed on a single occasion extremely high urinary levels of histamine unrelated to clinical condition or treatment. These high values have been excluded from the statistical analysis.

A comparison of the asthmatic and control groups with the normal subjects shows that the plasma histamine levels of the asthmatics on day 1 were significantly raised, in contrast to the whole blood levels, which are remarkably similar between the three groups. Treatment of asthmatic patients not only reduced the whole blood levels very greatly but restored the plasma levels to within the normal range. The urinary output of the control group of patients was significantly lower than that of normal subjects on all three days of the study; the plasma mean histamine level of this group rose during the 14 days' study and was, on day 14, significantly higher than that of both the normal subjects and the asthmatics (Table III).

Five of the asthmatic patients had received small doses of corticosteroids before admission to hospital. There was no difference between the histamine results in these and those who had not been on these drugs. Moreover, no difference was found in histamine levels between atopic and nonatopic patients.

Among individual patients, three asthmatics and one control subject showed initial plasma levels greater than two standard deviations above the normal mean. Two asthmatics and one control showed a similar increase in the initial whole blood histamine level.

\section{DISCUSSION}

Our results show that the plasma histamine levels of acute asthmatics are raised when compared with those of normal subjects. By contrast, whole blood levels are unchanged and urinary levels are slightly, but not significantly, reduced. Successful treatment with corticosteroids is associated with a sharp fall in whole blood histamine and a fall to normal of plasma histamine. In assessing the significance of the initial rise in plasma histamine, we have considered the possibility that errors of technique may have occurred due to separation of plasma in two different laboratories. However, from re-examination of our separative procedures, we do not feel that the buffy coat contaminated the samples taken from patients, and this is borne out by the lower plasma levels among the controls on day 1 and the asthmatic patients on days 3 and 14 .

Previous workers using sensitive bioassay techniques have failed to demonstrate histamine in plasma (Porter and Mitchell, 1970). Our results are consistent with these and those of Adam, Hardwick, and Spencer (1957) as the levels we detected were in general below the lower limits detectable by their techniques. Likewise, our results for whole blood in the asthmatics on day 1 and in the controls on all three days agreed well with those of Porter and Mitchell (1970) and of Dunér and Pernow (1958c), who used a chemical assay.

We chose to include a control group of nonasthmatic patients with serious respiratory disease in order to differentiate between changes in histamine related to asthma and those possibly related to a non-specific effect of illness. This has made the interpretation of certain of our results more difficult. Thus the plasma levels of the control group on day 1 occupied a position between those of the normal subjects and the asthmatics. Thereafter their mean plasma level rose until it was significantly higher than that of the normal subjects and, on day 14, of the same order as that of the acutely ill asthmatics. We have no satisfactory explanation of this, which may represent a nonspecific response to illness or wasting diseases or possibly to a change-over to hospital diet. Further investigation of this would be worth while. The 
fact that similarly high plasma histamine levels are found in the controls on day 14 and in the asthmatics on day 1 makes for caution in attributing a pathogenic role to histamine in these severely ill asthmatics.

Dunér and Pernow (1958a and b) have shown that a fall in urine histamine occurs with the onset of an acute asthmatic attack. The levels of histamine that we found in our asthmatic patients were lower (but not significantly lower) than those of our normals and of the patients of other investigators (Dunér and Pernow 1958a; Mitchell et al., 1974). Moreover, our control patients also had significantly low urinary histamine levels, though these rose pari passu with their rising plasma levels. Again it may be that the low levels in asthmatics represent a nonspecific effect of illness on histamine metabolism, although it should be noted that the urine collected on day 1 would have represented in part any effect that may have occurred as a result of the institution of treatment. It seems unlikely, however, from the low urinary levels on days 1 and 3 in the asthmatics that the histamine disappearing from the blood finds its way unchanged into the urine. While it may be that its metabolism is altered by steroid therapy, it is more likely that there is suppression of the circulation of basophil cells. Previous workers have suggested that the proportions of histamine to its metabolites in children are not altered in acute attacks of asthma or by maintenance steroid therapy (Mitchell et al., 1974).

The difficulties of interpreting the urinary histamine results are increased by the unexpected finding of very high levels on one occasion in three asthmatics. This may have represented an effect of steroid therapy, occurring as it did on day 1 in two subjects and on day 3 in one. It did not relate to any differences either in those patients' clinical condition or in their levels of blood histamine. A similar finding in one patient was recorded by Mitchell et al. (1954). We have never found such high levels in our normals nor in our control patients.

Whole blood histamine levels had partially recovered in the asthmatics by day 14 in spite of oral prednisone therapy in all patients. Previous workers have shown normal levels in children on long-term steroids (Porter and Mitchell, 1970) though a fall, related to blood basophil count after three days on hydrocortisone in adults (Code and Mitchell, 1957) and initial falls after adrenocorticotrophin (deGara, 1951) or oral prednisone (Noah and Brand, 1957), have been recorded.
Our results therefore indicate that histamine metabolism in severe asthma differs little from that in subjects suffering from other respiratory $\frac{\bar{c}}{\omega}$ illnesses. They point to three problems for further $\mathbb{D}$ study: (1) the possibility of nonspecific changes in histamine metabolism due to illness; (2) the metabolic fate of blood histamine after cortico- $\vec{\circ}$ steroid therapy; and (3) the interrelationships of $\exists$ histamine in arterial and venous blood and in sputum at the time of an acute attack of asthma, $\overrightarrow{\vec{x}}$ in order to investigate the role of lung tissue in $\underset{\omega}{x}$ the removal and metabolism of histamine in vivo.

\section{REFERENCES}

Adam, H. M., Hardwick, D. C., and Spencer, K. E. V. 음 (1957). A method of estimating histamine in plasma. British Journal of Pharmacology, 12, 397.

Aviado, D. M. and Carrillo, L. R. (1970). Anti- $\frac{\mathbb{}}{3}$ asthmatic action of corticosteroids: a review of the literature on their mechanism of action. (I) Journal of Clinical Pharmacology and Journal of $\vec{\oplus}$ New Drugs, 10, 3.

Beaven, M. A., Jacobsen, S., and Horáková, Z. (1971). Modification of the enzymatic isotopic assay of histamine and its application to measurement of histamine in tissues, serum and urine. Clinica Chimica Acta, 37, 91.

Code, C. F. and Mitchell, R. G. (1957). Histamine, 을 eosinophils and basophils in the blood. Journal of Physiology, 136, 449.

deGara, P. F. (1951). Chemical determination of 3 histamine in blood in health and disease. Journal of Allergy, 22, 429.

Dunér, H. and Pernow, B. (1958a). The correlation between the occurrence of histamine in bloodo and urine. Scandinavian Journal of Clinical and Laboratory Investigation, 10, 390.

Dunér, H. and Pernow, B. (1958b). Urinary excretion $\frac{0}{3}$ of histamine in bronchial asthma. Acta Medica Scandinavica, 161, 361 .

Dunér, H. and Pernow, B. (1958c). Histamine and leukocytes in blood during muscular work in응 man. Scandinavian Journal of Clinical and Laboratory Investigation, 10, 394.

Dunér, H. and Pernow, B. (1960). Histamine in man under physiological and pathological conditions. $N$ Acta Medica Scandinavica, 168, 307.

Herxheimer, H. (1951). Bronchial obstruction induced by allergens, histamine and acetyl-beta-methylcho- $\omega$ linechloride. International Archives of Allergy and Applied Immunology, 2, 27.

Lorenz, W., Reimann, H-J., Barth, H., Kusche, J., Meyer, R., Doenicke, A., and Hutzel, M.ळ (1972). A sensitive and specific method for the determination of histamine in whole blood and plasma. Hoppe-Seylers Zeitschrift für physi-웅 ologische Chemie, 353, 911.

Miller, R. L., McCord, C., Sanda, M., Bourne, H. R., and Melmon, K. L. (1970). Application of the 
enzymatic double isotope dilution assay for the study of histamine in plasma. Journal of Pharmacology and Experimental Therapeutics, 175, 228.

Mitchell, R. G., Logan, G. B., Peters, G. A., and Henderson, L. L. (1954). Urinary excretion of histamine in patients having asthma and hayfever; observations on changes produced by administration of cortisone. Journal of Allergy, 25, 504.

Mitchell, R. G., Thom, H., and Richardson, J. E. (1974). Histamine metabolism in asthma. Journal of Allergy and Clinical Immunology, 54, 111.

Noah, J. W. and Brand, A. (1957). The effect of corticosteroid administration upon blood histamine content. Journal of Allergy, 28, 405.

Porter, J. F. and Mitchell, R. G. (1970). The distribution of histamine in the blood of healthy and asthmatic children. Clinical Science, 38, 135.

Rose, B., Rusted, I., and Fownes, J. A. (1950). Intravascular catheterization studies of bronchial asthma. 1. Histamine levels in arterial and mixed venous blood of asthmatic patients before and during induced attacks. Journal of Clinical Investigation, 29, 1113.

Schild, H. O., Hawkins, D. F., Mongar, J. L., and Herxheimer, H. (1951). Reactions of isolated human asthmatic lung and bronchial tissue to a specific antigen: histamine release and muscular contraction. Lancet, $2,376$.

Snedecor, G. W. (1952). (Editorial Note). Biometrics, 8, 85-88.

Snyder, S. H., Baldessarini, R. J., and Axelrod, J. (1966). A sensitive and specific enzymatic isotopic assay for tissue histamine. Journal of Pharmacology and Experimental Therapeutics, 153, 544.

Requests for reprints to: Mrs. C. Bruce, Department of Chemical Pathology, Liverpool Area Health Authority (Teaching), Ashton Street, Liverpool L3 5RT. 